Sukhanov A.S.

\title{
CONTRIBUTIONS OF SERVICE MEN AND CLERKS \\ OF WESTERN SIBERIA IN THE SECOND HALF \\ OF THE XVII - BEGINNING OF THE XVIII CENTURIES \\ (BASED ON THE MATERIALS OF THE CONTRIBUTION BOOKS OF THE DALMATIAN ASSUMPTION MONASTERY)
}

Аннотация. Рассматриваются вклады служилых и приказных людей Западной Сибири второй половины XVII - начала XVIII веков по материалам двух вкладных книг Далматовского Успенского монастыря. Данные книги были описаны и сохранены В.П. Бирюковым и введены в научный оборот И.Л. Маньковой. Цель статьи заключается в анализе вкладов служилых корпораций, а также определении их численности среди населения региона. На основе анализа в таблице перечисляются основные категории служилого и приказного населения края и их семей. Всего зафиксировано 126 записей, из более чем 1300 вкладчиков. В статье прослеживается судьба знатных и незнатных представителей данных социальных групп и их роль в освоении Западной Сибири. Также рассматриваются военнополитические процессы, происходившие в Московском государстве и нашедшие свое отражение во вкладах данной группы населения. Затрагиваются служба детей боярских в Сибири, драгунская реформа тобольского воеводы П.И. Годунова, роль слободчиков и беломестного казачества в закреплении региона в составе государства. Кроме данных категорий, среди вкладов служилых людей упоминаются воротники, кречатные помыкальщики, ямщики, кузнецы и другие, а также показаны социальные изменения, происходившие внутри служилого населения края.

Ключевые слова: вкладные записи, служилые и приказные люди, слобода, острог, колонизация, Западная Сибирь

Сведения об авторе: Суханов Александр Сергеевич, Шадринский государственный педагогический университет, г. Шадринск, Россия, sukhanovas@mail.ru
Abstract. The article deals with the contributions of servants and clerks of Western Siberia in the second half of the XVII - early XVIII centuries based on the materials of two contribution books of the Dalmatov Assumption Monastery. These books were described and preserved by V.P. Biryukov and introduced into scientific circulation by I.L. Mankova. The purpose of the article is to analyze the contributions of service corporations, as well as to determine their number among the population of the region. Based on the analysis, the table lists the main categories of the military and military population of the region and their families. A total of 126 entries were recorded, out of more than 1300 contributors. The article traces the fate of the noble and non-noble representatives of these social groups and their role in the development of Western Siberia. The article also examines the military and political processes that took place in the Moscow state and were reflected in the contributions of this population group. The article deals with the service of the boyar children in Siberia, the dragoon reform of the Tobolsk voivode P. I. Godunov, the role of the Slobodchiks and the White Local Cossacks in consolidating the region as part of the state. In addition to these categories, among the contributions of service people are mentioned collars, gyrfalcon pomykalschiki, coachmen, blacksmiths and others. The article also shows the social changes that took place within the service population of the region.

Keywords: contribution records, serving and commanding people, sloboda, prison, colonization, Western Siberia

About the author: Sukhanov Alexander Sergeevich, Shadrinsk State Pedagogical University, Shadrinsk, Russia, sukhanovas@mail.ru

Введение. Далматовский Успенский монастырь один из старейших монастырей Зауралья и Западной Сибири. Основанная в 1644 году бывшим тобольским служилым человеком Дмитрием Ивановичем Мокринским (после пострига - Далмат) обитель была не 
только духовным центром Приисетья, но и важным военным форпостом для колонизации края.

Всего известно две вкладные книги обители. Первая датируется 1671 годом - «179 (1671) году книги Исецкие пустыни Успенского монастыря вкладчиком при Иосифе да при строителе старце Иосифе». Она охватывает вклады с 1671 по 1673 годы. На последних листах зафиксировано несколько записей 1677-1678 годов.

Вторая «Книга прикладная, денежная и скотская» начинается в 1673 году - «В нынешнем во 182-м (1673) году декабря в 7 день привели в Успенскую обитель...» В нее вошли вкладные записи с 1673 по 1703 годы.

Данные книги хранятся в ГКУ «Государственный архив в г. Шадринске» в фонде Далматовского Успенского монастыря (ф. 224), а также в виде фотокопий и списков в ГКУСО «Государственный архив Свердловской области» (ф. Р-2266).

Большую роль по сохранению данных источников провел В.П.Бирюков, уральский краевед, который смог в 1921 году вывезти архив Далматовского монастыря в г. Шадринск. Он высоко ценил данные книги, считая их важным источником по истории края, и настаивал на комплексном изучении вкладных записей.

Значительную работу по исследованию и введению в научный оборот данных источников сыграла кандидат исторических наук И.Л. Манькова, которая в 1992 г. опубликовала вкладные книги в сборнике документов «Вкладные книги Далматовского Успенского монастыря (последняя четверть XVII - начало XVIII в.)» [1]. Кроме текста книг, в данном сборнике имеются комментарии и приложения.

В данные книги вклады записаны в основном хронологически, но на некоторых листах есть более поздние записи, отражающие дополнительные пожертвования вкладчиков. Заполнение листов идет без учета социальной иерархии, записи высокопоставленных лиц не вынесены в начало, а включены в общий список.

Для человека позднего средневековья религиозное составляющее имело важное, если не первостепенное значение. Спасение души, забота о спасении душ родственников являлись неотъемлемой составляющей мировоззрения первопоселенцев. Кроме того, в те неспокойные годы население края могло рассчитывать, прежде всего, на себя, поэтому забота о дожитии ложилась на плечи не столько детей и родственников, сколько на плечи самих крестьян, драгун, беломестных казаков, не говоря уже о гулящих людях. Поэтому вклады можно условно разделить на две категории: во-первых, на помин своей души или родственников, знакомцев; во-вторых, вклады в монастырь, чтобы там, в спокойствии и мире окончить свой земной путь или принять иноческий постриг.

Большинство вкладчиков - это пашенные и оброчные крестьяне зауральских острогов, слобод и монастырей, именно они были той базой, которая обеспечивала продвижение государственной власти. Пермский историк А.А. Дмитриев утверждал, что «с усилением русской колонизации в Сибири развивалось земледелие, с тем вместе увеличивая класс служилых людей с его потребностями...» [2, с. 4]. Действительно, среди вкладных записей 
присутствуют данные о служилых и приказных людях Западной Сибири, как неотъемлемой части общества.

Всего в двух книгах содержатся данные о более чем 1300 вкладчиках, среди них есть и те, которые можно отнести к лицам и семьям служилого и приказного населения края (126 записей). Данные можно посмотреть в таблице.

Вкладчики Далматовского Успенского монастыря служилого и приказного населения и их семей Западной Сибири

\begin{tabular}{|l|c|}
\hline \multicolumn{1}{|c|}{ Должность } & Кол-во \\
\hline Думный дьяк, глава Сибирского приказа & 3 \\
\hline Тобольский воевода & 1 \\
\hline Стольник & 4 \\
\hline Дворянин & 2 \\
\hline Полуполковник & 1 \\
\hline Майор & 1 \\
\hline Слободчик & 15 \\
\hline Приказчик & 1 \\
\hline Сын боярский & 19 \\
\hline Прапорщик & 1 \\
\hline Драгун & 14 \\
\hline Драгун, толмач & 1 \\
\hline Служилый человек & 1 \\
\hline Атаман & 8 \\
\hline Воисковой подьячий & 4 \\
\hline Беломестный казак & 1 \\
\hline Конный казак & 1 \\
\hline Пеший казак & 3 \\
\hline Казак & 6 \\
\hline Воротник & 2 \\
\hline Кузнец & 2 \\
\hline Креча(т)ной помычник (помыкальщик) & 2 \\
\hline Ямской охотник (ямщик) & 1 \\
\hline Отставной драгун & 1 \\
\hline Бывший сотник & 126 \\
\hline Бывший беломестный казак & 1 \\
\hline Подьячий Сибирского приказа & 1 \\
\hline Дьяк, приказной подьячий (подьячий), писчий дьячок & 26 \\
\hline Целовальник таможенного ларещного & 1 \\
\hline Члены семей служилых людей & 2 \\
\hline Итого: & 1 \\
\hline
\end{tabular}

Большая часть вкладных записей данной группы относится к простым и незнатным жертвователям, тем на ком держался процесс освоения новых земель. Однако имеются вклады и высокопоставленных лиц, которые играли важное значение не только в регионе, но и Московском царстве в целом.

Например, запись о пожертвовании 15 золотых от царицы Прасковьи Федоровны, жены соправителя Петра I Ивана V [1, с. 92]. Любопытен также вклад в виде «двух книг московской печати» Думного дьяка, главы Сибирского приказа (1697-1704 гг.), сподвижника Петра I Виниуса А.А., [1, с. 156]. который посетил Тобольск по делам службы в 1702 г. 
Тобольские воеводы также легко отыскиваются между вкладчиками: стольник Хрущов Ф.Г. (1672-1673 гг.), боярин Головин А.П. (1686-1690гг.), ближний стольник Нарышкин А.Ф. (1693-1698 гг.). Примечателен вклад 1698 г. стольника Коровина С.Я. «животворящий крест серебряной, чеканной, вызолочен», который по указу состоял в числе посольства окольничьего Ф.А. Головина в Китай (1686-1689 гг.). Тогда, будучи молодым дворянином, он был послан с дипломатическим поручением в Пекин и привез ответ о назначении места встречи посольств под Селенгинском и определения войск сопровождения по 500 воинов с каждой стороны [3, с. 128, 140-142].

На листах 51, 282 об., 299, 307 об. «Книги прикладной, денежной и скотской» имеются записи о вкладах дворян, которых тоже можно отнести к служилым людям, так как все они состояли на государевой службе и на момент включения в источник выполняли те или иные должностные обязанности. Например, Гладышев Д.А., представитель уфимского дворянского рода Гладышевых, участник подавления башкирских восстаний 1662-1664 и 1681-1684 гг. Во время Крымского похода 1687 г. согласно Московского списка проявил отвагу и особо отмечено, что «он Дмитрий в Крыму татарского мурзу убил и сам ранен копьем в спину по обе стороны» [4]. В 1666 г. занимал должность стрелецкого головы в Уфе, был воеводой в Кунгуре в 1672,1685 и 1686 гг.

Качанов И.Р., московский дворянин, писец, на момент вкладной записи (1700г.) проводил перепись населения вотчины Далматовского монастыря, а также являлся автором в 1700 г. Тюменской переписной, в 1701 г. Тарской переписной книг. На его вклад (50 рублей) была построена церковь в честь Введения во храм Пресвятой Богородицы в СвятоВведенском женском монастыре [1, с. 140].

Арсеньев А.М., московский дворянин, в 1692 г. стольник при царице Евдокие Федоровне, первой жене Петра I, в 1697 году упоминается как сын якутского воеводы М.А. Арсеньева [5, с. 474].

На страницах вкладных книг отражена деятельность немногочисленного офицерского корпуса. Полуполковник рейтарского строя Волков И.С. помимо военных выполнял и административные функции «приказного человека» в Шадринской слободе. После вклада 1671 года, есть запись о его кончине 2 сентября 1672 г., захоронении на территории обители, а также значительных пожертвованиях на помин души [1, с. 11].

Во второй книге упоминается тюменский боярский сын, полуполковник Текутьев С.И. [1, с. 140], который за три года до вклада, в 1697 г. переписал новоприборных крестьян уезда.

Майор А.Н. Фефилов в 1668 г., после передачи из Верхотурского уезда в Тобольский Катайского острога, был направлен туда воеводой Годуновым П.И. и выполнял также военные и административные функции. Во второй книге отмечены два его вклада 1679 и 1680 гг. В ней же имеются и вклады его жены Евдокии Ивановны - 1685 г., где Алексей Фефилов фигурирует, как бывший тобольский житель, а также 1702 г., где Евдокия Ивановна именуется «Катайского острогу вдова..., Алексея маера упокойного жена». Судя по всему, после смерти мужа она осталась жить в Катайском остроге. 
Администрация слобод представлена вкладами слободчиков и приказчика. В книгах имеются записи о пожертвованиях основателей слобод и занимавших должности слободчиков Беляковской, Барневской, Окуневской, Калиновской, Красномысской (Красномыльской), Белоярской, Чумлякской, Камышевской, Верхиртышской. Слободчики играли важную административно-организационную роль в освоении Западной Сибири. Как правило, являясь выходцами из крестьянской среды, мелкого купечества или беломестного казачества на свой страх и риск, используя собственные финансовые возможности, они обустраивали первые слободы Зауралья [6, с. 32]. Привлекали крестьян и гулящих людей «на государеву десятинную пашню». При этом прибранным крестьянам предоставлялся льготный период от нескольких месяцев до нескольких лет без уплаты оброка. Слободчик брал с крестьян «поручные записи», по которым они и после истечения льготных лет должны были проживать в слободе и пахать государеву десятину. Кроме этого, ими «прибирались» беломестные казаки, которые отвечали за оборону населенных пунктов. Население слобод под руководством основателей заботилось о возведении и поддержании оборонительных укреплений в надлежащем виде. По мнению Кондрашенкова А.А., выдача печати, а также возложенные обязанности делали слободчиков низшим представителем государственной администрации [7, с. 55-56]. Приказчики приходили на смену слободчикам, выполняли те же функции и являлись государственными должностными лицами.

Сыновья боярские или дети боярские, служилое сословие, появившееся в Московском государстве в XV веке, они верстались на службу, получая денежное жалование и земельные наделы. В Сибири данная служилая корпорация появляется на рубеже XVI-XVII вв. Например, в гарнизоне Тобольска в 1627 г. зафиксировано 36 детей боярских. Первоначально эта небольшая группа к концу века значительно возрастает. Так, в Тобольске с 1628 по 1685 гг. корпорация детей боярских увеличилась в 7 раз. Являясь военной элитой, в Сибири они выполняли как военные, так и административные функции, а также исполняли особые поручения тобольских воевод $[8$, с. 156, 158]. Во вкладных книгах присутствуют 15 записей, относящихся к данной социальной группе: 8 вкладов тобольских, 4 - софийского архиерейского дома в Тобольске, 3 - верхотурских сыновей боярских.

Вот некоторые из них. Тырков М.И. верхотурский сын боярский (с 1663 г.), принадлежавший к роду Тырковых, внесших значительный вклад в освоение Сибири. В 1660-х годах приказчик Катайского острога, в 1666 году участвовал в земельном споре с Далматовским монастырем [1, с. 170]. Чаплин И.В. тобольский сын боярский, скорее всего сын подьячего Василия Чаплина, погибшего в составе посольства Ерофея Заболоцкого в Монголию в 1650 г. [9, с. 347, 348].

Софийские дети боярские принадлежали к архиерейскому дому в г. Тобольске, они подчинялись митрополиту и играли значительную роль в управлении епархии. В конце XVII в. их числилось 20 в Тобольском архиерейском доме. Кроме военных обязанностей, «они занимались управлением вотчинами, выполняли различные поручения, служили посыльными, представляли интересы митрополита в различных инстанциях, были «стряпчими» [10, с. 128]. Трех из четырех можно отыскать в Поименном списке чинов 
Тобольского архиерейского дома Степан Казими(е)ров, братья Коркишевы (в списке Карташевы), Осип Плавин (в списке Главин) [10, с. 132-133].

Во вкладных книгах нашла отражение реформа воеводы Годунова П.И. 1667-1669 гг. по формированию драгунских полков.

Первые полки «иноземного строя» появились в Московском государстве при Михаиле Федоровиче в 1630-1632 гг. в количестве 10 (8 солдатских, 1 рейтарский и 1 драгунский) всего около 17000 человек. В 1636-1638 гг. солдатские и драгунские полки появляются на юге страны для борьбы с кочевниками. В середине 1630-х гг. подобные формирования появляются в Сибири. Вскоре (1639 г.) данные соединения, как наиболее боеспособные, принимают участие в удачном походе против енисейских киргизов, которые терпят серьезное поражение и возобновляют выплату дани. Удачное применение «иноземного строя» против кочевников, а также желание усилить военное присутствие в регионе приводят к тому, что в 1658 гг. Алексей Михайлович решает сформировать полки «нового строя» в Сибири. Предусматривалось создать полк рейтар (1000 человек) и солдатский полк (1000 человек), а также увеличить количество стрельцов до 500. К 1662 г. это удалось сделать лишь частично, так как основной проблемой была нехватка кадров, особенно офицеров [11, с. 110-113]. В финансовом же плане создание новых подразделений стало возможным из-за денежной реформы Алексея Михайловича, предусматривающей выпуск медных денег. После Медного бунта 1662 г., провала денежной реформы и запрещения хождения медной монеты в Сибири (1663 г.) возникают перебои с выплатой жалования чинам полков «нового строя». Именно поэтому, тобольский воевода Годунов П.И. планировал создание одного драгунского полка численностью 1200 человек, так как рядовые драгуны получали по 5 рублей и 2 с четвертью пуда соли в год, что соотносилось с жалованием беломестных казаков, а также единовременно 2,5 рубля на лошадь и 1,5 рубля на постройку дома. Жалование же рейтар составляло от 15 до 20 рублей в год, что было крайне накладно для государства, ведущего затяжную войну с Речью Посполитой 16541667 гг. Кроме этого была озвучена и официальная версия о преимуществе драгун над рейтарами и об их универсальных качествах «а драгун в походе конный, а и пеш драгун солдат же» [11, с. 115-117]. Драгуны несли гарнизонную службу, а также участвовали в отражении нападений кочевников. В основном они были набраны из беломестных казаков, а также солдат, гулящих людей, хотя есть примеры перевода в драгуны пашенных крестьян. Ведров Иван драгун Масленской слободы, по переписи 1669 года был монастырским крестьянином, в этом же году по государеву указу был отдан Малечкину Ю.Н. для строительства слободы на р. Масленке [1, с. 169].

Реформа Годунова П.И. потерпела неудачу, прежде всего потому, что бывшие рейтары и солдаты не спешили записываться в драгуны с меньшим окладом. К 1674 г. из 730 поверстанных в драгуны половина разбежалась. В 1671 г. в острогах и слободах по р. Исети числилось 438, а в 1674 г. там же уже 386 драгунов. Окончательно сибирские драгуны исчезли в 1689 году, путем перевода их в беломестные казаки [11, с. 119-120]. Это подтверждается данными вкладных книг, по которым из 20 вкладов драгунов 17 сделаны в 
промежутке между 1673 и 1685 гг., 3 относятся к периоду 1692-1701 гг. Примечательно, что в 1701 году вкладные записи сделаны уже об отставленных драгунах Масленской слободы Ильиных Петре и Воденикове Василии. Несмотря на то, что в 1689 г. драгуны были переведены в беломестные казаки, 7 декабря 1701 г. зафиксирован денежный вклад «Катайского острогу у драгуна Ивашка Тарасова Раевых по усопших родителей» [1, с. 150]. Все эти данные позволяют сделать вывод об исчезновении драгунов, как вида служилых людей на рубеже XVII-XVIII вв.

После неудачи реформы некоторые драгуны переходили в те социальные слои, откуда были поверстаны на службу. Так, Горсткин Яков в 1673 г. делает вклад как драгун Шадринской слободы, а в 1680 г. уже как пашенный крестьянин той же слободы. Заслуживает внимания запись о вкладе Панкратьева Трофима драгуна-толмача из Катайского острога, которая фиксирует специфичность должностных обязанностей. Всего во вкладных книгах имеется 20 записей, относящихся к этой группе служилых людей.

В 14 вкладах фигурируют просто служилые люди - «служилой», «служивой человек», «тобольский служивый человек», «Уфимскаго города служилый человек». Все они выполняли разные военные и административные обязанности, состояли на государственной службе. 11 октября 1702 г. «тобольской служилой человек» Семен Максимов привез в обитель вклад (5 рублей) тобольского приказного подьячего Ивана Слонова [1, с. 156]. Яков Золотарь в 1674 г. делает вклад как «служилой человек» Катайского острога, а в 1676 году уже как драгун того же острога.

Опорой государства на вновь колонизированных территориях, являлось, в том числе и казачество. Со времен Ивана IV Грозного казаки охраняли южные рубежи Московского государства, получая жалование и земельные наделы. Значительную роль казачество сыграло в Смутном времени, после которого наблюдается рост численности данной служилой корпорации. Сам термин, по мнению некоторых историков (Миллер Г.Ф., Татищев В.Н., Фишер И.Е.), связан с наделением казаков, так называемой «белой» землей, свободной от налогов [12, с. 71]. То есть беломестные казаки должны были выполнять службу за не большое жалование (обычно от 2 до 5 рублей), а также земельный надел (20-30 четвертей) с которого не выплачивался оброк [12, с. 82]. Первые беломестные казаки в Сибири появились в 1630-е гг., к осени 1634 г. они состояли в гарнизонах Верхней Ницинской (10 человек) и Нижней Ницинской (10 человек) слободах. В 1635 г. беломестные казаки появились в Невьянской (17 человек) и Новой Ницинской (30 человек) слободах [12, с. 72-73].

В казаки верстались пашенные крестьяне, охочие и гулящие люди. Это были первые воинские формирования способные закрепить вновь приобретенные территории за Московским царством. Первоначально это были небольшие группы, занятые военноадминистративной службой в слободах и острогах Западной Сибири. В дальнейшем, в связи с возросшей угрозой нападений кочевников численность данной группы служилых людей увеличивалась. Например, в Тобольском уезде к концу XVII в. количество беломестных казаков составляло 992 человека, размещались они сотнями в крупных слободах и острогах, располагавшихся на юго-востоке уезда [12, с. 79]. Такое размещение было связано с 
активизировавшимися кочевниками и возможностью быстрого сбора значительных сил при военной угрозе. Данная служилая корпорация исчезает в Западной Сибири к концу правления Петра I, после проведения первой сибирской ревизии (1724 г.) беломестные казаки вошли в состав податного населения [12, с. 82]. Во вкладных книгах Успенской обители представлены записи от атамана до рядового казака.

13 сентября 1684 г. зафиксирован вклад атамана Исетского острога Афанасия Давыдова, можно предположить, что это сын основателя данного острога конного казака Давыда Андреева. Относительно Мехонской слободы имеется запись о вкладе войскового подьячего, представителя военной администрации. Во вкладных книгах отражены пожертвования беломестных казаков Катайского острога, Камышловской, Красномысской, Пышминской Ощепковской и Масленской слобод. Не редки случаи вкладов с последующим постригом в монахи, например, вклад 1672 г. беломестного казака Катайского острога Терентия Карпова, в иночестве Тимофея [1, с. 16]. Примечательно, что сведения о конных и пеших казаках относятся только к представителям городов Тюмени (3 конных казака) и Тобольска (1 казак, 1 пеший казак, 1 конный казак).

Наряду с беломестными казаками гарнизонную службу в слободах несли пушкари, затинщики, сторожа, воротники. Сведений о данной категории служилых людей в книгах имеется три, все они относятся к вкладам воротников Катайского острога, Барневской и Бачанской слобод.

Важную вспомогательную роль в острогах и слободах выполняли кузнецы. Обслуживание конных служилых людей, изготовление и ремонт оружия и сельскохозяйственного инструмента являлись повседневными обязанностями данной группы населения. Зафиксированные 6 записей также можно отнести к вкладам приказных и служилых людей края, данный факт подтверждается сведениями из «Росписи зауральских слобод (1686 г.)», где кузнецы стоят в ряду «пушкарей и затинщиков и воротников и толмачей» $[13$, с. 26].

К служилым людям относятся и креча(т)ные помычники или помыкальщики. Люди, занимавшиеся ловлей кречетов и соколов, обучением хищных птиц и их поставкой к царскому двору. Известна царская грамота верхотурскому воеводе Ивану Пушкину о поставке в Москву ко двору «самых лучших кречатов и челиг кречатьих», где упоминаются помыкальщики. [5, с. 36]. При этом данная категория служилых людей несла не только хозяйственную службу, но и являлась обычной военной силой в столкновениях с кочевниками. В книгах зафиксированы два вклада данной корпорации служилых людей Ощепковской слободы Гаврилы Берсенева [1, с. 51] и Афанасия Ощепкова [1, с. 46].

Ямская служба известна на Руси со времен татаро-монгольского нашествия, суть ее заключалась в перевозке людей и грузов, за так называемую прогонную плату. За Уралом ямская гоньба, по мнению Семенова О.В., появилась на рубеже XVII-XVIII вв. [14, с. 198]. Ямы устраивались, как правило, через 30-40 верст, это можно проследить по географии основания слобод в Западной Сибири. В крупных сибирских городах возникали ямские слободы (Верхотурье, Тобольск, Тюмень), где проживали ямщики и ямские охотники. 
Каждый ямщик должен был исполнять службу на своих лошадях, которая была тяжелой и опасной. В источнике присутствуют две записи о вкладах тюменских ямщиков на помин своей души и родственников [1, с. 25,38$]$.

В книгах отмечены и бывшие служилые люди, которые за «старостию» не могли выполнять своих прямых обязанностей (бывший сотник, беломестный казак, «отставленные» драгуны). Например, Аврамий Муравьев, бывший беломестный казак Камышевской слободы за вклад был пострижен под именем Андреян [1, с. 34]. Для того чтобы стать вкладчиком нужно было внести в обитель деньгами или другим имуществом не мене 10 рублей [1, с. 175]. Сотник и отставные драгуны принадлежали Масленской слободе и сделали вклады на помин души своих родственников.

Освоение края было бы невозможно без представителей администрации, данная социальная группа зафиксирована во вкладах дьяков, подьячих, таможенных чиновников разных уровней. Так, Василий Павлов, подьячий Сибирского приказа, Яков Костромин, подьячий приказной палаты г.Тобольска, Сысой Вахов, подьячий Красномысской слободы, то есть представлены все уровни государственной администрации: столичный, уровень Тобольского разряда и слободской уровень. Должностное лицо, занимающееся взиманием налогов и таможенных сборов, представлено вкладами тобольского таможенного ларещного целовальника Василия Гробова по своим родственникам и по своему бывшему начальнику таможенному голове Василию Саватиеву [1, с. 152].

Определенный интерес вызывают вкладные записи членов семей служилых и приказных людей. Вдова майора, жена пятидесятника, жены детей боярских, драгуна, беломестного казака, дочь конного казака зафиксированы в книгах. Среди них заслуживают внимания вклады вдовы тобольского сына боярского Толбузина Л.Б. Толбузиной К.С. В 1703 г. ею пожертвованы по тем временам значительные суммы, 10 рублей 20 февраля и 20 рублей 1 марта. Такие денежные средства вложены в обитель не случайно, так как на государевой службе у Каптелины Степановны в 1676 г. умерли муж Ларион Борисович и сын Фадей, а младший сын Алексей погиб во время осады Албазинского острога в 1686 г. Все они были поверстаны в сыновья боярские и выполняли важные военные и административные поручения тобольских воевод. В разное время Ларион занимал воеводские должности в Нерчинске (1662-1668 гг.), Тюмени (1671-1676 гг.), Фадей занимал должность воеводы в Березове (1670-1672 гг.), Алексей Толбузин руководил Нерчинским уездом с 1676 по 1680 гг., а с 1683 года был воеводой Албазина, выдержал осаду 1685 года, но погиб во время второй осады в 1686 году [15, с. 31-35].

На страницах второй книги в 1695 г. зафиксирован вклад детей по родителям своим еще одной известной фамилии в Сибири - Шульгиных. Так, Шульгин П.Я тобольский сын боярский проводил досмотр земель Далматовского монастыря в 1651 г. В 1673 году был послан в Нерчинский острог на воеводство. Скончался в Даурах в 1678 г. по нему и сделан был посмертный вклад в монастырь [1, с. 175]. Его сын Василий Шульгин возглавлял отряд тобольских детей боярских, беломестных казаков, служилых татар в неудачной битве против казахов у оз. Семискуль 27 июля 1693 г. Вместе с Василием погибли его братья Яков и Иван, 
всего 357 служилых и охочих людей, из отряда уцелело 14 человек, которые в дальнейшем сбежали из плена [16, с. 340-341].

Заключение. Вкладные записи служилых и приказных людей, а также членов их семей составляют менее $10 \%$ в источниках, что говорит о немногочисленности данной группы населения Западной Сибири. Осваивая значительные пространства, государство испытывало крайние затруднения с кадрами, которые пополнялись как за счет местных внутренних резервов, так и присылкой немногочисленных воинских формирований из центральных регионов Московского государства, а также ссыльных и военнопленных групп служилых людей. И, все-таки, даже такие небольшие формирования решали важные военноадминистративные задачи, что в конечном итоге предопределило вхождение в состав державы территории Сибири и Дальнего Востока. Таким образом, вкладные книги Далматовской Успенской обители, могут быть использованы не только как важный источник религиозной жизни Западной Сибири, но и как ценное свидетельство колонизации края и участия в нем служилого и приказного населения.

\section{Литература}

1. Вкладные книги Далматовского Успенского монастыря (последняя четверть XVII начало XVIII в.): Сб. документов. Сост. И.Л. Манькова. Свердловск: Ин-т истории и археологии, 1992. 244 с.

2. Дмитриев А.А. Пермская старина: сборник исторических статей и материалов преимущественно о Пермском крае / [соч.] Александра Дмитриева. Пермь: Издание автора, 1899-1900. Вып. 8: К истории зауральской торговли. Башкирия при начале русской колонизации. М.: Типография наследников П. Ф. Каменского. 1900. 172 с.

3. Яковлева П.Т. Первый русско-китайский договор 1689 года. М.: Издательство Академии наук СССР, 1958. 212 с.

4. Азнабаев Б.А. Уфимское дворянство в конце XVI - первой трети XVIII века. Уфа: РИЦ БашГУ, 2000. 191 с.

5. Акты исторические, собранные и изданные Археографической комиссией. Т. 5. Тип. II-го Отделения Собственной Е.И.В. Канцелярии СПб.: Тип. Экспедиции заготовления государственных бумаг, 1842. 567 с.

6. Грачёв В.Ю., Займогов А.И., Попова Л.Д. Слободы и Слободчики Урала. Екатеринбург: Грачёв и партнеры, 2014. 74 с.

7. Кондрашенков А.А. Крестьяне Зауралья в XVII-XVIII веках. Ч. 1. Заселение территории русскими. Челябинск, 1966. 176 с.

8. Пузанов В.Д. Русская военная политика и колонизация Западной Сибири (конец XVI - начало XVIII в.). LAP LAMBERT Academic Publishing (Германия), 2011. 568 с.

9. Златкин И.Я., Устюгов Н.В. Русско-монгольские отношения. 1634-1654. М.: Наука. 1974. $472 \mathrm{c}$.

10. Свящ. Иоанн Никулин Структура Тобольского архиерейского дома в 90-е годы XVII в. // Вестник Екатеринбургской духовной семинарии. 2014. Вып. 2(8). С. 120-138. 
11. Пузанов В.Д. Русские полки «иноземного строя» в Сибири в XVII в. (статья) // Вопросы истории. 2006. № 7. С. 110-121.

12. Пузанов В. Д. Беломестные казаки в Сибири XVII - первой трети XVIII в. // Вопросы истории. 2012. №10. С. 71-86.

13. Хрестоматия по истории Курганской области (досоветский период). Курган: Зауралье, 1995. 319 с.

14. Семенов О.В. О времени возникновения системы регулярного сообщения в Сибири // Известия Алтайского государственного университета. Серия: История, Политология. Журнал теоретических и прикладных исследований. 2010. № 4/2 (68/2). С. 198-200.

15. Пузанов В.Д. Род Толбузиных - воевод Забайкалья в XVII веке // Приграничный регион в историческом развитии: партнёрство и сотрудничество: материалы междунар. науч. конф. Чита: ЗабГУ, 2017. С. 31-35.

16. Полное собрание русских летописей. Т. 36. Сибирские летописи. Ч. 1. Группа Есиповской летописи. М.: Наука, 1987. 384 с.

\section{References}

1. Vkladnye knigi Dalmatovskogo Uspenskogo monastyrya (poslednyaya chetvert' XVII nachalo XVIII v.): Sb. dokumentov. Sost. I.L. Man'kova (1992). Sverdlovsk. (In Russian).

2. Dmitriev, A.A. (1900). Permskaya starina: sbornik istoricheskikh statei i materialov preimushchestvenno o Permskom krae. Perm' Izdanie avtora, 1899-1900. In K istorii zaural'skoi torgovli. Bashkiriya pri nachale russkoi kolonizatsii. Moscow. (In Russian).

3. Yakovleva, P.T. (1958). Pervyi russko-kitaiskii dogovor 1689 goda. Moscow. (In Russian).

4. Aznabaev, B.A. (2000). Ufimskoe dvoryanstvo v kontse XVI - pervoi treti XVIII veka. Ufa. (In Russian).

5. Akty istoricheskie, sobrannye i izdannye Arkheograficheskoi komissiei. 5. (1842). St. Petersburg. (In Russian).

6. Grachev, V.Yu., Zaimogov, A.I., \& Popova, L.D. (2014). Slobody i Slobodchiki Urala. Ekaterinburg. (In Russian).

7. Kondrashenkov, A.A. (1966). Krest'yane Zaural'ya v XVII-XVIII vekakh. 1. Zaselenie territorii russkimi. Chelyabinsk. (In Russian).

8. Puzanov, V.D. (2011). Russkaya voennaya politika i kolonizatsiya Zapadnoi Sibiri (konets XVI - nachalo XVIII v.). Germaniya. (In Russian).

9. Zlatkin, I.Ya., \& Ustyugov, N.V. (1974). Russko-mongol'skie otnosheniya. 1634-1654. Moscow. (In Russian).

10. Svyashch (2014). Ioann Nikulin Struktura Tobol'skogo arkhiereiskogo doma v 90-e gody XVII v. Vestnik Ekaterinburgskoi dukhovnoi seminarii, 2(8), 120-138. (In Russian).

11. Puzanov, V.D. (2006). Russkie polki «inozemnogo stroya» v Sibiri v XVII v. (stat'ya). Voprosy istorii, (7), 110-121. (In Russian).

12. Puzanov, V. D. (2012). Belomestnye kazaki v Sibiri XVII - pervoi treti XVIII v. Voprosy istorii, (10), 71-86. (In Russian). 
13. Khrestomatiya po istorii Kurganskoi oblasti (dosovetskii period) (1995). Kurgan. (In Russian).

14. Semenov, O.V. (2010). O vremeni vozniknoveniya sistemy regulyarnogo soobshcheniya v Sibiri. Izvestiya Altaiskogo gosudarstvennogo universiteta. Seriya: Istoriya, Politologiya. Zhurnal teoreticheskikh i prikladnykh issledovanii, (4/2 (68/2)), 198-200. (In Russian).

15. Puzanov, V.D. (2017). Rod Tolbuzinykh - voevod Zabaikal'ya v XVII veke. Prigranichnyi region $\mathrm{v}$ istoricheskom razvitii: partnerstvo i sotrudnichestvo: materialy mezhdunar. nauch. konf. Chita. 31-35. (In Russian).

16. Polnoe sobranie russkikh letopisei (1987). In Sibirskie letopisi. 1. Gruppa Esipovskoi letopisi. Moscow. (In Russian).

Суханов А.С. Вклады служилых и приказных людей Западной Сибири второй половины XVII начала XVIII веков (по материалам вкладных книг Далматовского Успенского монастыря) // Вестник Нижневартовского государственного университета. 2021. № 3(55). С. 72-83. https://doi.org/10.36906/2311-4444/21-3/07

Sukhanov, A.S. (2021). Contributions of service men and clerks of Western Siberia in the second half of the XVII - beginning of the XVIII centuries (based on the materials of the contribution books of the Dalmatian Assumption monastery). Bulletin of Nizhnevartovsk State University. (3(55)). 72-83. (In Russian). https://doi.org/10.36906/2311-4444/21-3/07 